KULTURA

i

\title{
POSTRZEGANIE DEMOKRACJI A KAPITAŁ SPOŁECZNY STUDIUM PORÓWNAWCZE Z TERENÓW PODLASIA I BRANDENBURGII
}

Podlasie i Brandenburgia to dwa regiony europejskie, w których demokracja ma względnie krótką historię. Przełom ustrojowy lat 1989/1990 przyniósł ze sobą zmiany niekoniecznie jednoznacznie pozytywne i dobrze oceniane przez mieszkańców tych regionów. W pierwszych latach transformacji całą Polskę i nowe kraje związkowe w Niemczech charakteryzowały wysoka inflacja i rosnące bezrobocie. W regionach określanych jako peryferyjne, takich jak niemiecka Brandenburgia i polskie Podlasie, procesy te były szczególnie nasilone i widoczne. Rosły nierówności społeczne, a wraz z nimi — grupa niezadowolonych i tych, którzy z nostalgią wspominali dawny, „sprawiedliwszy” system. Mówiąc o tym, nie należy zapominać, ile pozytywnych zmian przyniósł ze sobą system demokratyczny - wolne wybory, wolność głoszenia i reprezentowania poglądów, dostęp do informacji, prawo zrzeszania się i działania w organizacjach politycznych i obywatelskich, możliwość definiowania dobra wspólnego i sposobów działania na jego rzecz. Pytanie brzmi, czy nie są to tylko puste slogany, pojęcia czysto teoretyczne, definicje tworzone przez polityków czy intelektualistów, które nie odgrywają żadnej roli w życiu przeciętnego obywatela. Jak ważna dla obywateli europejskich regionów postsocjalistycznych jest demokracja oraz fakt życia w systemie demokratycznym? Jak ludzie postrzegają demokrację i jakie czynniki decydują o obrazie demokracji w ich oczach?

\section{WYBÓR REGIONÓW}

Opisane tu badania dotyczą postrzegania demokracji w kontekście zasobów i jakości kapitału społecznego wybranych społeczności. Badania miały charak-

Adres do korespondencji: ewa.m.bacia@gmail.com 
ter socjologiczny, opierały się przede wszystkim na metodach jakościowych, a przeprowadzono je w latach 2007-2008 na Podlasiu ${ }^{1}$ i w Brandenburgii. Do badań celowo wybrano regiony postrzegane w swoich krajach jako biedne, słabo rozwinięte gospodarczo obszary peryferyjne. O takim ich statusie decyduje szereg czynników, takich jak: położenie wobec centrum gospodarczo-kulturowego, historia, struktura demograficzna czy sytuacja na rynku pracy. Podlasie i Brandenburgia rozwijają się wolniej niż pozostałe regiony krajów, w których się znajdują. Młodzi ludzie opuszczają te tereny w poszukiwaniu pracy i w nadziei na lepszą przyszłość. Niewielu świadomie podejmuje decyzję o powiązaniu swej przyszłości z pracą i życiem w Brandenburgii czy na Podlasiu i z działalnością na rzecz rozwoju tych regionów. Większość młodzieży, która ma szansę na wyjazd i dalsze życie poza Podlasiem i Brandenburgią, korzysta z niej. Swe rodzinne regiony często traktują w sposób sentymentalny, powracając do nich, by odwiedzić rodziny i miejsca związane $z$ dzieciństwem i wczesną młodością. Lata aktywności spędzają jednak z dala od lokalnych ojczyzn, gdzie pozostają przede wszystkim ludzie starsi oraz tacy, którzy nie mają możliwości i/bądź chęci do podejmowania innowacyjnych i kreatywnych działań w obszarze życia społecznego i zawodowego.

Peryferyjny charakter regionów sprawia, że są one szczególnie godne przebadania w kontekście rozumienia demokracji przez ich mieszkańców. Mają oni bowiem z pewnością inną perspektywę postrzegania demokracji i swojego wpływu na rzeczywistość społeczno-polityczną niż obywatele dobrze rozwiniętych regionów centralnych. Ich poziomy życia różnią się. Prawdopodobnie ma to wpływ na postawy obywatelskie oraz postrzeganie systemu demokratycznego, dlatego istotne jest, by w obszarach peryferyjnych badać aktywne postawy obywatelskie oraz gotowość do angażowania się $\mathrm{w}$ działania na rzecz społeczności lokalnej.

W badaniach uwzględniono zarówno poziom mikro, dotyczący bezpośredniej demokracji lokalnej, jak i poziom makro, odnoszący się do mechanizmów demokracji reprezentatywnej. Analiza materiału empirycznego bazowała na prowadzonych od lat w naukach społecznych i politycznych debatach na temat kryzysu demokracji, ze szczególnym uwzględnieniem teorii postdemokracji Colina Croucha. Badano również kapitał społeczny jako czynnik, który może mieć wpływ na zachowania społeczne i wizję demokracji w oczach członków danej wspólnoty.

\section{WYBÓR TEORII}

Wybór koncepcji kapitału społecznego oraz postdemokracji jako ujęć teoretycznych systematyzujących badania jest uzasadniony kilkoma argumentami.

\footnotetext{
1 Przez Podlasie rozumiem tu województwo podlaskie w granicach administracyjnych po reformie administracyjnej z $1999 \mathrm{r}$.
} 
Kapitał społeczny został w badaniach zdefiniowany jako system powiązań między członkami danej społeczności oparty na zaufaniu, wspólnych normach, wartościach i zapatrywaniach na rzeczywistość społeczną. W koncepcji tej zakłada się, że oddziaływanie kapitału społecznego wzmacnia wspólnotę, oznacza bowiem większą aktywność społeczną, zaangażowanie obywatelskie i troskę o dobro wspólne. Kapitał społeczny powinien więc być nieodłącznym elementem demokracji oddolnej. Społeczności o wysokim poziomie kapitału społecznego powinno cechować duże zaufanie do instytucji demokratycznych i sposobu ich funkcjonowania, a także osobiste zaangażowanie ich członków w strukturach o charakterze demokratycznym.

Teoria postdemokracji - w opozycji do koncepcji kapitału społecznego zakłada, że zaufanie do demokracji w społeczeństwach określanych jako demokratyczne jest obecnie bardzo niskie, ponieważ ludzie dostrzegli, że mają znikomy wpływ na warunki, w których żyją. Jest tak, ponieważ nie sami obywatele decydują o warunkach życia w swoim regionie, lecz instytucje rzadko działające na demokratycznych zasadach. $Z$ tego powodu zaangażowanie obywatelskie oraz zaufanie do instytucji maleje. Ponieważ ludzie nie widzą celowości podejmowania wspólnych działań, sieci powiązań społecznych są słabe, nie działa się na rzecz pielęgnacji jednolitego systemu norm i wartości.

Skąd wybór akurat tych dwóch ujęć teoretycznych? Przedstawiają one skrajnie różne sposoby postrzegania i „przeżywania” demokracji. Teoretycy kapitału społecznego podkreślają przede wszystkim pozytywny wpływ na życie wspólnotowe istniejących więzi bazujących na zaufaniu i wspólnych normach. Teoretycy postdemokracji zaś mówią o zamieraniu życia wspólnotowego oraz o coraz wyraźniejszej granicy między sferą prywatną a odległą z perspektywy przeciętnego obywatela sferą publiczną, do której nie przynależą obywatele, lecz tylko ci nieliczni, którzy decydują o warunkach życia znacznej większości.

\section{KAPITAŁ SPOŁECZNY}

Obecnie stwierdza się kryzys społeczeństwa obywatelskiego i brak rozwoju tam, gdzie słabe są więzi społeczne. „Badania i dane statystyczne wskazują wyraźnie na to, iż «spoiwo społeczne» puszcza we wszystkich obszarach - rodziny ulegają rozpadowi, stowarzyszenia i partie polityczne tracą członków, kurczą się wspólnoty wyznaniowe, za to powszechny staje się egoistyczny chaos" (Gehmacher 2004). Za skuteczny środek zaradczy przeciw kryzysowi społecznemu współczesnych społeczeństw przez wielu badaczy uznawany jest kapitał społeczny, rozumiany jako element niezbędny do wytworzenia się spójności i współpracy społecznej, solidarności i zmysłu wspólnotowego. Jest to pojęcie $z$ pogranicza ekonomii i socjologii, łączące $\mathrm{w}$ sobie dwa sposoby postrzegania rzeczywistości. $Z$ ekonomicznego punktu widzenia „[k]apitał społeczny to cecha charakteryzująca społeczności, w tym także narody i społeczeństwa narodowe, która przejawia się tym, że członkowie tych społeczności są skłonni 
do nawiązywania transakcji (ekonomicznych i nieekonomicznych) dzięki temu, że postrzegane ryzyko tych transakcji jest mniejsze niż postrzegane korzyści" (Fazlagić b.d.).

W teorii, w odwołaniu do pracy Ferdinanda Tönniesa Wspólnota $i$ stowarzyszenie, wprowadza się podział na wspólnotową i zrzeszeniową formę kapitału społecznego. Kapitał społeczny typu wspólnotowego jest charakterystyczny dla wspólnot tradycyjnych, przeddemokratycznych. Kapitał typu zrzeszeniowego to element przynależny światu sprawnie funkcjonującej demokracji. Postdemokracja mówi o końcu tego świata wraz z pojawieniem się systemów instytucjonalnych działających z pominięciem mechanizmów demokratycznych. Czy przyjmując takie odniesienia rozwoju demokracji można określić, na jakim etapie znajduje się Podlasie, a na jakim Brandenburgia? Czy możliwe jest w tych przypadkach określenie kierunku rozwoju? Czy regiony te zmierzają w tym samym kierunku? Czy na podstawie analizy wyników badań można mówić o stabilnej demokracji w peryferyjnych regionach krajów postsocjalistycznych? Czym jest demokracja w rzeczywistości społeczno-politycznej Podlasia i Brandenburgii?

\section{POSTDEMOKRACJA}

Punktem wyjściowym rozważań nurtu postdemokratycznego jest stwierdzenie, że obywatel ma coraz mniejszy wpływ na funkcjonowanie struktur demokratycznych oraz na podejmowanie decyzji kształtujących warunki brzegowe życia w krajach o ustroju demokratycznym. Brytyjski profesor ekonomii Colin Crouch $(2004$, s. 2), analizując współczesny kryzys demokracji, rozumie ją jako system, w którym „[...] zwykli obywatele mogą w różnych formach uczestniczyć $\mathrm{w}$ życiu publicznym - poprzez udział $\mathrm{w}$ dyskusji i działalność niezależnych organizacji mają wpływ na kształtowanie porządku publicznego - i, co więcej, aktywnie korzystają z tych możliwości".

W postdemokracji instytucje demokracji parlamentarnej wprawdzie funkcjonują wciąż jeszcze według zasad demokratycznych — odbywają się wybory, prowadzi się kampanie polityczne, partie polityczne zabiegają o głosy wyborców, zachowany jest podział władzy - ale działanie polityczne nie jest już legitymowane udziałem obywateli $\mathrm{w}$ życiu publicznym, partycypacją obywatelską. Kampanie polityczne stają się kontrolowanymi przedstawieniami, dla których scenariusze piszą konkurujące ze sobą grupy specjalistów od reklamy i public relations. „Określają one agendę polityczną przez wybór, a następnie uwypuklenie niewielu tematów, które są ponadto coraz silniej personalizowane. Tłum ludzki odgrywa przy tym wyłącznie pasywną, milcząca, niekiedy nawet apatyczną rolę, niezdolny do brania udziału w dysputach politycznych. Właściwy proces polityczny przebiega za kulisami tego spektaklu gry wyborczej. Odbywa się on w formie prywatnych kontaktów wybranych rządów i elit, 
które reprezentują przede wszystkim interesy lobby gospodarczego" (Jörke 2005, s. 483).

Postdemokracja państw zachodnich oznacza więc, według Croucha, trwanie instytucji demokratycznych, czemu towarzyszy świadomość zmiany systemu politycznego. Nieco inaczej rozumieją to pojęcie Sheldon Wolin (2001), który sięgając po teorię Tocqueville'a opisuje wpływ społeczeństwa konsumpcyjnego na demokrację Stanów Zjednoczonych, czy Jacques Rancière (1997) analizujący ograniczenia aktywności politycznej przez badania opinii publicznej. Zwolennicy wszystkich tych ujęć są zgodni co do jednego: demokracja ewoluuje od zaangażowania obywatelskiego ku anonimowej, zbiurokratyzowanej postdemokracji.

„Idea postdemokracji pomaga nam opisać sytuację, w której po czasie demokracji nastały znudzenie, frustracja i utrata iluzji; interesy silnej mniejszości zwyciężyły nad masą zwykłych ludzi i system polityczny działa na rzecz tej mniejszości; elity polityczne nauczyły się rządzić i manipulować oczekiwaniami społecznymi; ludzie są agitowani do głosowania przez odgórnie kierowane kampanie reklamowe. [...] We współczesnych społeczeństwach rozwiniętych widocznych jest bardzo wiele symptomów tego, że oddalamy się coraz bardziej od maksymalistycznego ideału demokracji w kierunku modelu postdemokratycznego" (Crouch 2004, s. 19-20).

Obywatel przestaje być podejmującym najistotniejsze decyzje suwerenem państwa demokratycznego, a staje się obiektem, którego głównym zadaniem jest konsumenckie reagowanie na wymagania rynku światowego. $\mathrm{W}$ przeciwieństwie do ujęcia teorii pluralistycznych zakłada się teraz, że dobro wspólne może być określone odgórnie, a konflikty interesów mogą być rozwiązane przez pracę gremiów i urzędów wykonawczych, z pominięciem mechanizmów demokratycznych. Kompetencje do działania zostają przypisane rozmaitym grupom eksperckim, komisjom i koncernom gospodarczym. Teoretycy postdemokracji mówią o zamieraniu wszelkiego życia wspólnotowego i o coraz wyraźniejszym rozdziale sfery prywatnej i publicznej. Ta ostatnia jest coraz bardziej odległa od zwykłego człowieka. Przynależą do niej tylko nieliczni, którzy mają możliwość podejmowania decyzji.

Przeciętny obywatel skupia się na życiu prywatnym i zawodowym, nie angażuje się w życie wspólnoty. Frekwencja wyborcza spada, ludzie coraz mniej interesują się polityką, struktury i mechanizmy demokratyczne tracą na znaczeniu, zachowując jedynie znaczenie formalne. Władza jest w rękach mediów i organizacji ponadnarodowych, decyzje zapadają odgórnie, więc nie sposób wywrzeć realnego wpływu na jakość życia przez oddolną aktywność społeczną. Demokracja bazująca na sieciach relacji i współpracy między obywatelami zamiera. W postdemokracji decydujące znaczenie mają struktury hierarchiczne. Decyzje dotyczące obywateli zapadają niezależnie od ich aktywności czy pasywności. 


\section{GŁÓWNE PYTANIA BADAWCZE}

Celem opisywanych badań było znalezienie odpowiedzi na pytanie, która $z$ dwóch przedstawionych wyżej teorii lepiej opisuje i tłumaczy realne procesy rozwoju demokracji w wybranych regionach. Poszukiwano odpowiedzi na następujące pytania badawcze:

— Jakie jest wśród respondentów rozumienie pojęcia demokracji?

- Jak respondenci oceniają funkcjonowanie demokracji w swoim regionie?

- Jak respondenci rozumieją pojęcie obywatela i postawy obywatelskiej?

- Czym jest dla respondentów pojęcie dobra wspólnego?

- W jakim stopniu mieszkańcy badanych regionów zainteresowani są funkcjonowaniem władz (różnych szczebli) wyłonionych w wyniku wyborów demokratycznych, na przykład lokalnych i regionalnych samorządów czy parlamentu krajowego?

- Jak duże jest wśród mieszkańców zainteresowanie funkcjonowaniem innego typu instytucji (nie bazujących na strukturach demokratycznych), takich jak międzynarodowe korporacje gospodarcze?

- W jakim stopniu respondenci darzą zaufaniem instytucje oparte na demokratycznych mechanizmach funkcjonowania, a w jakim - instytucje opierające swą działalność na innych zasadach?

- Jak duże jest wśród mieszkańców poczucie wpływu na rzeczywistość i kulturę polityczną i gospodarczą wyznaczającą ramy ich działania?

- W jakim stopniu i w jaki sposób badani próbują kształtować tę rzeczywistość (udział w wyborach demokratycznych, udział w działalności partii politycznych, aktywność obywatelska $\mathrm{w}$ stowarzyszeniach, fundacjach itp.)?

- Czy respondenci wykazują zaangażowanie i chęć wspólnego działania na rzecz regionu?

- Czy zaufanie do instytucji i aktywność obywatelska mają związek z poczuciem przynależności do wspólnoty lokalnej/regionalnej/państwowej (poczucie przynależności jest tu rozumiane jako poczucie wspólnoty norm i wartości w ramach grupy, do której przynależymy)?

- Czy istnieją sieci kontaktów między obywatelami? Jak one funkcjonują? Czy dominują zależności oparte na strukturach pionowych czy poziomych?

- Jakie jest nastawienie członków badanej społeczności do członków innych grup (kooperacyjne, niechętne czy obojętne)?

\section{HIPOTEZY BADAWCZE}

Najważniejsze hipotezy badawcze brzmiały:

1. Kapitały społeczne społeczności badanych regionów - Podlasia i Brandenburgii - wykazują znaczące różnice. Są to kapitały innego rodzaju, nierówne są również ich zasoby w badanych społecznościach. 
2. Postrzeganie demokracji w regionach postsocjalistycznych jest zależne od źródeł i rodzaju kapitału społecznego w tych regionach. Duży kapitał społeczny kształtuje pozytywny obraz demokracji u obywateli.

3. Duży kapitał społeczny wyklucza możliwość opisania rzeczywistości w kategoriach postdemokratycznych. Mały kapitał społeczny jest kompatybilny $z$ tezami teorii postdemokracji.

\section{METODY I TECHNIKI BADAŃ, JEDNOSTKI BADAWCZE}

Badania miały charakter jakościowy. Zgodnie z zasadą triangulacji użyto różnych metod i technik badawczych, wśród nich znalazły się:

1) wtórna analiza danych $z$ badań związanych $z$ tematem;

2) analiza danych dotyczących historii, gospodarki, zagadnień demograficznych, społecznych i politycznych regionów;

3) analiza dokumentów urzędowych;

4) wywiady zogniskowane przeprowadzone w sześciu wybranych miejscowościach z „przeciętnymi” mieszkańcami;

5) wywiady pogłębione $z$ przedstawicielami regionalnych elit — członkami władz samorządowych, głównymi pracodawcami, działaczami organizacji pozarządowych, lokalnymi liderami, dziennikarzami itp. (blisko 80).

Były to zarówno badania porównawcze, jak i case study - studium obejmujące sześć rozmaitych miejscowości w dwóch regionach. Miejscowości zostały wybrane ze względu na następujące zmienne niezależne: stopień urbanizacji, miejsce $\mathrm{w}$ układzie centrum-peryferie regionu, sytuacja demograficzna oraz ekonomiczna. Dobór ze względu na te czynniki miał umożliwić uzyskanie przekroju cech regionów. Ze względu na skrajne wartości zmiennych zależnych możliwe jest uogólnienie wyników na całość regionów.

Po przeanalizowaniu przyjętych kryteriów zdecydowano się na wybór następujących miejscowości:

- Białystok, Łomża i Krynki na Podlasiu;

- Poczdam, Frankfurt nad Odrą i Letschin w Brandenburgii.

Poczdam i Białystok to stolice i największe miasta regionów. Są to ośrodki centralne, wokół których koncentruje się życie regionów. Mają w nich swe siedziby główne instytucje o zasięgu regionalnym, tu zapadają ważne decyzje dotyczące Brandenburgii i Podlasia. Sytuacja ekonomiczna Poczdamu i Białegostoku jest lepsza niż pozostałych miast i wsi w regionie. Tu skupiają się największe inwestycje, a bezrobocie jest niższe niż w ośrodkach peryferyjnych.

Łomża i Frankfurt nad Odrą to miasta liczące nieco ponad 63000 mieszkańców. Kilkunastoprocentowe bezrobocie plasuje je na średnich pozycjach ze względu na stopę bezrobocia $\mathrm{w}$ regionach. Saldo migracji to niewielka liczba ujemna, a poziom rozwoju miast jest przeciętny. 
Krynki i Letschin to wsie ${ }^{2}$ podobnej wielkości, liczące około 2000 mieszkańców. Położone są na peryferiach regionu. Obie miejscowości leżą w obszarze nadgranicznym, gdzie od wieków ścierały się wpływy różnych kultur, języków i religii. Problemami Krynek i Letschina są wysokie bezrobocie, stagnacja ekonomiczna oraz konieczność przekwalifikowywania się. W obydwu wsiach dominuje ludność starsza, a młodzi wyjeżdżają z rodzinnej miejscowości w poszukiwaniu pracy. I Letschin, i Krynki przeżywają problemy niestabilności ekonomicznej, ujemnego salda migracji i niepewności jutra.

\section{KAPITAŁ SPOŁECZNY PODLASIA I BRANDENBURGII — WERYFIKACJA PIERWSZEJ HIPOTEZY}

Badania potwierdziły pierwszą z postawionych hipotez. Kapitał społeczny Brandenburgii jest większy niż kapitał społeczny Podlasia. W podsumowaniu wyników brano pod uwagę różne elementy składowe kapitału:

1. Kapitał stowarzyszeniowy: członkostwo w organizacjach dobrowolnych, stowarzyszeniach, związkach itp., rodzaj organizacji i charakter członkostwa, ich znaczenie i wpływ na społeczność.

2. Kapitał wspólnotowy: powiązania między członkami wspólnoty, siła stosunków sąsiedzkich i życia wspólnotowego, występowanie struktur horyzontalnych i hierarchicznych, rodzaj, siła i funkcjonowanie sieci współpracy.

3. Tożsamość lokalna i regionalna, wspólne normy i wartości.

4. Znaczenie kategorii dobra wspólnego i postawy obywatelskiej dla członków wspólnoty.

5. Przepływ informacji i metody przezwyciężania konfliktu interesów w ramach wspólnoty i poza nią.

Pierwszy z wyróżnionych komponentów, kapitał związany z funkcjonowaniem organizacji, jest znacznie silniejszy w Brandenburgii niż na Podlasiu. Brandenburgia ma silne tradycje stowarzyszeniowe, funkcjonowanie organizacji pozarządowych jest tu od dawna elementem krajobrazu społecznego gmin i jest przez większość mieszkańców traktowane jako naturalny element tego krajobrazu. Jak wykazało badanie wykonane w 2006 r., około 33\% obywateli Brandenburgii pracuje społecznie (TNS 2006). Jako główne czynniki motywujące do uczestnictwa w organizacjach społecznych badani podają chęć do współtworzenia życia wspólnoty, działanie na rzecz dobra wspólnego, kontakty towarzyskie z ludźmi o podobnych zapatrywaniach i zainteresowaniach oraz udział w procesach politycznych. Tego rodzaju motywacje są silną bazą aktywnego społeczeństwa obywatelskiego, którego sednem jest świadome działanie obywateli na rzecz wspólnoty.

\footnotetext{
2 W styczniu 2009 r. Krynki zyskały prawa miejskie, jednak w czasie prowadzenia badań była to wieś.
} 
Na Podlasiu komponent stowarzyszeniowy jest dużo słabiej rozwinięty. Brakuje tradycji stowarzyszania się, a często też chęci do podejmowania wspólnej aktywności. Należy jednak zwrócić uwagę na to, że w ostatnich latach rozwijają się tu profesjonalnie zarządzane, nastawione na pozyskiwanie środków unijnych organizacje pozarządowe. Ich działanie nakierowane jest często na obszary wiejskie, których mieszkańcy w większości pozostają pasywni w sferze społecznej, narzekają prezentując postawę niezadowolenia, przy jednoczesnym braku chęci do działania. Mieszkańcy Brandenburgii również często narzekają. Różnica polega na tym, że Niemcy w sytuacji niezadowolenia częściej wykorzystują możliwości działania, by choć w małym stopniu zmienić rzeczywistość wokół siebie.

Drugi komponent kapitału społecznego, intensywność życia wspólnotowego, w obydwu regionach jest silniejszy na obszarach wiejskich niż w miastach. Jak na całym świecie, życie na wsi jest tu mniej anonimowe i w większym stopniu oparte na bezpośrednich kontaktach dobrosąsiedzkich. Jednak w wyniku transformacji ustrojowej życie wspólnotowe uległo znacznym przeobrażeniom. Stało się słabsze. Jako przyczyny tego stanu rzeczy respondenci w obu krajach podawali trudną sytuację na rynku pracy, problemy finansowe, brak czasu, a na Podlasiu także coraz powszechniejsze myślenie w kategoriach konkurencji i tendencje do indywidualizacji.

$\mathrm{Na}$ Podlasiu bardziej niż w Brandenburgii ugruntowane jest myślenie w kategoriach hierarchicznych. Instytucje polityczne często są tu postrzegane jako struktury funkcjonujące niezależnie od obywateli. Większość mieszkańców nie interesuje się ich pracą i z tej przyczyny nie potrafi jej ocenić. Kontrola społeczna instytucji jest słaba, za to oczekiwania są wysokie. Oczekuje się, że ludzie na stanowiskach znajdą rozwiązania problemów społeczności. W wielu przypadkach taka postawa staje się usprawiedliwieniem własnej pasywności. W Brandenburgii kontrola społeczna instytucji lokalnych i regionalnych jest silniejsza. Oczekiwania są równie wysokie, jednak nastawienie, że radzenie sobie z problemami całej społeczności to tylko i wyłącznie zadanie instytucji, nie jest tak rozpowszechnione jak na Podlasiu. Instytucje częściej są tu postrzegane jako partner do współpracy niż jako dostarczyciel potrzebnych usług. W Brandenburgii za partnerów uważa się przedstawicieli instytucji trzech sektorów: publicznego, prywatnego i pozarządowego. Rozwijają się tu sieci współpracy, dyskutuje się i realizuje wspólne projekty. Na Podlasiu współpraca instytucji wciąż jeszcze jest w powijakach, brakuje ponadto dobrej bazy jej rozwoju. Dwie trzecie badanych uważało, że współpraca między instytucjami publicznymi a przedsiębiorstwami jest $\mathrm{w}$ ogóle niemożliwa, ponieważ interesy polityczne i gospodarcze są niemożliwe do uzgodnienia. Również przedstawiciele organizacji pozarządowych opowiadali o słabej współpracy międzysektorowej. Organizacje pozarządowe na Podlasiu wciąż jeszcze w wielu środowiskach są traktowane jako konkurencja i czynnik zaburzający procesy podejmowania decyzji i rządzenia. 
Kapitał społeczny w Brandenburgii wiele zawdzięcza rozwiniętej tożsamości regionalnej jej mieszkańców. Większość respondentów deklarowała tam bowiem silną identyfikację $z$ regionem wzmacniającą myślenie $\mathrm{w}$ kategoriach rozwoju całego regionu. Brandenburczycy są zakorzenieni w swoich lokalnych społecznościach, uwzględniają jednak przy tym dobro całego regionu. Na Podlasiu sytuacja w tym względzie jest dużo bardziej skomplikowana, ponieważ tożsamość regionalna nie jest dostatecznie rozwinięta. Większość identyfikuje się z obszarem dawnych województw - białostockim, łomżyńskim i suwalskim. Niektórzy przejawiają wręcz postawę niechęci wobec konkurentów z pozostałych podregionów.

Jeśli chodzi o sferę norm i wartości, to przeprowadzone badania wykazały, że w Brandenburgii silniejsze jest myślenie w kategoriach prospołecznych, choć i tu dostrzec można tendencję do indywidualizacji i atomizacji społecznej.

Różnice w nastawieniu do celów wspólnoty wyraźne odzwierciedlają się w różnym definiowaniu dobra wspólnego. W Brandenburgii dobro wspólne nierzadko jest utożsamiane ze sprawiedliwością społeczną. Praca na rzecz dobra wspólnego wykonywana jest zarówno na poziomie krajowym, tam gdzie państwo powinno dbać o równe szanse dla wszystkich, jak i na poziomie lokalnym - mieszkańcy w swoich gminach sami dbają o zaspokojenie własnych potrzeb. Dobro wspólne jest tu rozumiane jako naturalne dążenie, bez którego nie może funkcjonować żadna wspólnota. Uwidacznia się to w zaangażowaniu i postawie obywatelskiej tych, którym zależy, by „nam wszystkim” lepiej się żyło. Nie rozwiąże się $\mathrm{w}$ ten sposób, co prawda, wszystkich problemów, nie uzupełni wszelkich społecznych deficytów, jednak bez myślenia w kategoriach dobra wspólnego życie wspólnoty nie ma racji bytu.

Tyle o Brandenburgii. Na Podlasiu rozumienie dobra wspólnego jest zupełnie inne. Nie jest tu ono traktowane jako coś oczywistego i naturalnego w życiu wspólnoty. Dla większości respondentów jest to kategoria teoretyczna, nieuchwytna idea, bądź też coś, co istnieje niezależnie od obywateli, jak dziedzictwo kulturowe, tradycja i historia, troska o ojczyznę i dążenie do szczęśliwości. Przeciętny obywatel nie myśli o dobru wspólnym i nie dostrzega zależności między dobrem wspólnym a zaangażowaniem obywatelskim. O ile w Brandenburgii zaangażowanie obywatelskie przede wszystkim jest rozumiane jako aktywność społeczna w swoim środowisku, o tyle na Podlasiu definiuje się je jako dziś już rzadką cnotę dbałości o ojczyznę. W Brandenburgii postawa obywatelska to aktywne zaangażowanie mieszkańców w życie wspólnoty, a na Podlasiu niekiedy uważa się wręcz, że dobry obywatel to taki, który „nie przeszkadza władzy w rządzeniu, nie wtrąca się w pracę samorządu i nie krytykuje jej”. Postawa obywatelska na Podlasiu jest kojarzona, inaczej niż $\mathrm{w}$ Brandenburgii, raczej z państwem i wielką polityką niż z zaangażowaniem $\mathrm{w}$ gminie czy w regionie. Obywatel reprezentujący postawę obywatelską angażuje się, gdy ojczyzna jest w potrzebie. Wtedy ma okazję pokazać, że jest patriotą. Ponieważ patriotyzm w dzisiejszym, globalizującym się świecie 
ma coraz niższą rangę, również postawa obywatelska jest czymś, co odchodzi w przeszłość.

Na gruncie teorii kapitału społecznego uważa się, że silny kapitał społeczny ułatwia rozwiązywanie konfliktów interesów. Przeprowadzone badania wykazały, że ludzie w wysokim stopniu identyfikujący się ze swoją wspólnotą i zaangażowani społecznie wykazują większą skłonność do kompromisów z tymi członkami wspólnoty, którzy zgłaszają inne interesy. Jedna z niemieckich respondentek, mieszkanka Poczdamu, zdefiniowała system demokratyczny jako taki, w którym każdy obywatel ma własną opinię i jest zdolny do zawierania kompromisów. Demokracja lokalna przy takim podejściu jest rozumiana jako aktywność mieszkańców skłonnych do debaty i zawierania kompromisów. Na Podlasiu postrzeganie demokracji lokalnej jest zupełnie odmienne. Tu rzadko wspomina się o chęci debatowania o sprawach dotyczących całej wspólnoty. Słyszy się raczej nawoływania, by władzę zostawić w spokoju, tak by mogła wykonywać swoje zadania.

Konflikty interesów w Brandenburgii często są rozwiązywane z wykorzystaniem istniejących struktur. Współpraca nie zawsze układa się bezkonfliktowo, jednak gdy występuje jakiś problem społeczny, istnienie ukształtowanych struktur umożliwia poznanie opinii i argumentów drugiej strony. Daje to szansę uwzględnienia potrzeb wszystkich zainteresowanych. Brak struktur współpracy na Podlasiu sprawia, że konflikty interesów są trudniejsze do przezwyciężenia, a środowiska mające różne zapatrywania na daną kwestię pozostają wobec siebie sceptyczne i nieufne. Stanowisko przeciwnej strony konfliktu interesów często jest słabo znane ze względu na ograniczony obieg informacji. W Brandenburgii częściej podejmuje się próby poznania i zrozumienia argumentów przeciwnika i zawarcia kompromisu.

Po przeanalizowaniu poszczególnych aspektów kapitału społecznego Podlasia i Brandenburgii rozważę jeszcze dwie kwestie, bezpośrednio związane z postawionymi na wstępie hipotezami badawczymi: Czy badane społeczności da się wpisać w któryś model kapitału społecznego, na przykład model kapitału wspólnotowego i stowarzyszeniowego? I drugie pytanie: Jaki jest związek kapitału społecznego i sposobu postrzegania demokracji?

$\mathrm{Na}$ Podlasiu z powodu nieukształtowania tożsamości regionalnej i słabych więzów między członkami wspólnoty trudno jest mówić o kapitale społecznym całego regionu. W miastach widoczne są zaczątki nowoczesnej formy stowarzyszeniowej kapitału społecznego. Powstają nowe struktury i profesjonalnie zarządzane organizacje obywatelskie. Proces ich rozwoju osłabia brak silnych więzi i myślenia o wspólnocie w kategoriach dobra wspólnego. Nie można tu jeszcze mówić o w pełni ukształtowanym modelu kapitału społecznego typu stowarzyszeniowego, istnieją jednak przesłanki pozwalające prognozować dalszy rozwój kapitału tego typu w większych miastach Podlasia.

Sytuacja na wsi jest bardziej złożona. Na wielu obszarach, przede wszystkim na wschodzie regionu, dominuje postawa pasywna, brakuje organizacji obywa- 
telskich, nie rozwijają się sieci współpracy. $\mathrm{Na}$ innych obszarach, zwłaszcza na terenie byłego województwa łomżyńskiego, występuje jeszcze silny kapitał typu wspólnotowego, przede wszystkim wśród przedstawicieli starszych pokoleń. Młodsi częściej myślą w kategoriach osobistego sukcesu i własnego dobrobytu, a nie rozwoju wspólnoty. Może to skutkować stopniowym zanikiem kapitału typu wspólnotowego na tych obszarach.

W Brandenburgii różnice między poszczególnymi podregionami nie są tak duże, wyraźne są natomiast różnice między kapitałem społecznym miast i wsi. W miastach silny jest kapitał stowarzyszeniowy, z profesjonalnymi organizacjami pozarządowymi i rozwiniętymi sieciami współpracy. Struktury te orientują się na wartości społeczne i myślenie w kategoriach dobra wspólnego. Oczywiście nie jest tak, że w sferę społeczno-publiczną angażuje się większość mieszkańców, jednak aktywna elita jest na tyle liczna, że można mówić o silnym kapitale stowarzyszeniowym w dużych miastach Brandenburgii.

Kapitał społeczny brandenburskiej wsi jest kapitałem typu wspólnotowego $z$ tendencją do rozwoju profesjonalnie zarządzanego kapitału stowarzyszeniowego. Mieszkańcy wsi często się wspierają, co przybiera mniej lub bardziej sformalizowaną formę. $Z$ jednej strony jest to pomoc dobrosąsiedzka, $z$ drugiej strony działalność wielu stowarzyszeń, związki i programy współpracy. Również i tu nie wszyscy się angażują. Bezrobotni i ubodzy są zagrożeni marginalizacją społeczną, czemu próbuje się przeciwdziałać, wykorzystując dostępne wspólnotom zasoby kapitału społecznego.

Społeczności Podlasia i Brandenburgii nie dadzą się zamknąć ściśle w znanych modelach kapitału społecznego. Kapitał społeczny tych regionów jest zróżnicowany i ulega ciągłym przekształceniom w związku ze zmianami społeczno-politycznymi, ekonomicznymi i demograficznymi. Czy istnienie poszczególnych rodzajów kapitału społecznego kształtuje formę polityczną badanych społeczności i ma wpływ na postrzeganie demokracji przez ich członków?

\section{POSTRZEGANIE DEMOKRACJI PRZEZ MIESZKAŃCÓW BADANYCH REGIONÓW}

Badania wykazały, iż ani Podlasie, ani Brandenburgia nie dadzą się w pełni opisać za pomocą jednego z modeli obrazujących kontinuum rozwoju od społeczności przeddemokratycznych przez te $\mathrm{w}$ pełni demokratyczne po postdemokratyczne.

Zacznijmy od Podlasia. Społeczności wiejskie nie są tu formą społeczeństwa przeddemokratycznego, ponieważ brakuje silnych powiązań społecznych i zaangażowania społecznego. Nie są również formą w pełni demokratyczną, ponieważ mieszkańcy podlaskiej wsi w bardzo małym stopniu interesują się pracą instytucji demokratycznych i wykazują znikome zaangażowanie polityczne. Czy są może postdemokratyczne? Też niezupełnie. Większość respondentów uważała, że instytucje lokalne i krajowe wciąż mają większy wpływ na warunki życia niż instytucje ponadnarodowe. Zupełnie pomijano w wypowiedziach znaczenie 
koncernów gospodarczych. Oznaki rozwoju w pełni demokratycznego modelu można dostrzec $\mathrm{w}$ miastach - powstają tam bazujące na wartościach demokratycznych organizacje obywatelskie. Jednak dla miast Podlasia charakterystyczne jest specyficzne rozumienie demokracji. Respondenci pytani o ocenę procesu transformacji ustrojowej w Polsce mówią zazwyczaj wyłącznie o zmianie swojej sytuacji finansowej. Zainteresowanie polityką wiąże się z nadziejami na wzrost dobrobytu. Ludzie chętnie rozmawiają o polityce i na nią narzekają, co nie przekłada się jednak na realną aktywność w sferze publicznej. Prezentowany tu system wartości jest silnie materialistyczny, wiele osób, z którymi przeprowadzono wywiady, nie odróżnia kapitalizmu od demokracji.

Podsumowując można powiedzieć, że społeczność Podlasia znajduje się między formą tradycyjną i postdemokratyczną. W czasach PRL-u nie mogło się ukształtować społeczeństwo w pełni demokratyczne. Po transformacji proces ten też nie był łatwy i oczywisty. Brakowało odpowiednich wzorców i elit. Obywatele Podlasia oczekują od demokracji ochrony wolności i zapewnienia bezpieczeństwa socjalnego. Partycypacja polityczna ogranicza się dla nich do udziału w wyborach. Nieufność wobec polityków i przekonanie o bardzo małym wpływie na warunki życia $\mathrm{w}$ kraju i $\mathrm{w}$ regionie są elementami nastawienia postdemokratycznego. Czy można jednak w społeczeństwie, w którym nie do końca wykształcił się model demokratyczny, mówić o postdemokracji?

Brandenburgia za to znajduje się między demokratyczną a postdemokratyczną formą rozwoju społeczności. Demokracja lokalna funkcjonuje tu bardzo dobrze, mimo że frekwencja wyborcza również nie jest bardzo wysoka. Ludzie uważają jednak, że poprzez aktywność na poziomie lokalnym mają możliwość osiągania celów ważnych dla wspólnoty oraz urzeczywistniania swojej wizji życia społecznego, jednak nie tak dalece, by zapobiec wykluczeniu społecznemu długotrwale bezrobotnych i ubogich. Zaangażowani lokalnie obywatele często narzekają na niedoskonałe funkcjonowanie demokracji na wyższych poziomach administracyjnych. Krytyka dotyczy nie tylko — jak na Podlasiu — konkretnych osób i wydarzeń z kręgu polityki, lecz samych podstaw systemu demokratycznego we współczesnym, coraz bardziej złożonym i globalizującym się świecie. $Z$ jednej strony wskazuje to na krytyczne zainteresowanie sferą polityczną, co może świadczyć o dobrej kondycji społeczeństwa demokratycznego, z drugiej strony taki stan rzeczy może okazać się groźny, jeżeli w wątpliwość podane będą fundamentalne zasady systemu demokratycznego. A taka tendencja jest w Brandenburgii zauważalna. Gdy pada pytanie: „Co my właściwie mamy z tej całej demokracji? Za NRD było sprawiedliwiej i bezpieczniej”, albo gdy obywatele zupełnie rezygnują z uczestnictwa w życiu społeczno-politycznym, wtedy można już mówić o silnych tendencjach postdemokratycznych. Znaczące jest jednak, że ludzie angażujący się lokalnie chcą korzystać $z$ istniejących struktur politycznych, by reprezentować swe interesy na różnych poziomach zarządzania. Krytykują system, ale mimo to korzystają z możliwości, które ten system im stwarza, by w ten sposób ewentualnie go reformować i udoskonalać. 


\section{KAPITAŁ SPOŁECZNY A POSTRZEGANIE DEMOKRACJI — WERYFIKACJA DRUGIEJ HIPOTEZY}

Przeprowadzone badania potwierdzają hipotezę, iż kapitał społeczny ma znaczący wpływ na postrzeganie demokracji i postawy obywatelskie. Należy przy tym uwzględniać poszczególne aspekty kapitału społecznego. Poziom i rodzaj kapitału społecznego badanych społeczności wykazuje duże różnice, co uwarunkowane jest odmienną historią i tradycją zamieszkiwanych przez nie obszarów. Silny kapitał społeczny Brandenburgii powoduje, że mieszkańcy tego regionu bardziej niż mieszkańcy Podlasia doceniają możliwości działania, które daje im demokracja na poziomie lokalnym. Chodzi tu o aktywność polityczną i przede wszystkim społeczną, która rozwija się na tym poziomie i może być rozszerzona również na poziomy dalsze - regionalny, krajowy i ponadnarodowy. Wysoki poziom kapitału społecznego buduje lepszy obraz demokracji w oczach mieszkańców. Na Podlasiu większa jest pasywność, wiele osób nie angażuje się w żaden sposób w sferę publiczną. Nie angażuje się i nie widzi możliwości zmiany czegokolwiek. Także i tu kapitał społeczny — rozumiany jako aktywność społeczna - silnie wpływa na obraz i ocenę demokracji w oczach obywateli.

Zależność między postrzeganiem demokracji a innym komponentem kapitału społecznego - zaufaniem - nie jest znacząca. Trzeba tu rozróżnić dwa rodzaje zaufania. Zaufanie zgeneralizowane do innych ludzi wzmacnia gotowość do angażowania się w sferze społecznej i przez to pozytywnie wpływa na postrzeganie demokracji. Gdy ufamy innym, chętnie z nimi współpracujemy, by efektywniej osiągać ważne dla siebie cele. Zaufanie zaś do polityków i instytucji demokratycznych - jak stwierdzono, niskie zarówno na Podlasiu, jak i w Brandenburgii - nie ma znaczącego wpływu na zaangażowanie polityczne obywateli. Natężenie tego rodzaju zaufania wskazuje jedynie, jak obywatele oceniają znanych sobie polityków i instytucje, nie mówi jednak wiele o tym, jak oceniają demokrację jako system i czy są gotowi w ramach tego systemu aktywnie działać.

Trzeci element kapitału społecznego — wspólne normy i wartości - w dużym stopniu kształtuje rozumienie demokracji. W Brandenburgii wiele celów i projektów społeczno-politycznych koncentruje się wokół dobra wspólnego. Dobro wspólne nie jest tu traktowane jako puste hasło, a myślenie w kategoriach dobra wspólnego wzmacnia mocno zarysowana tożsamość regionalna. Mieszkańcy Brandenburgii postrzegają siebie jako wspólnotę ukształtowaną przez czynniki historyczne, kulturowe i społeczno-polityczne, jako wspólnotę, która dąży do osiągnięcia pewnych celów, co jest łatwiejsze w państwie demokratycznym niż przy innej formie rządów. Myślenie w kategoriach tego, co wspólne, wzmacnia bowiem pozytywne rozumienie demokracji. Na Podlasiu tożsamość regionalna nie jest ukształtowana, a dobro wspólne jako wartość nie jest zakorzenione w świadomości ludzkiej. Coraz silniejsze są tu tenden- 
cje do indywidualizacji. Możliwości wspólnego działania w ramach systemu demokratycznego są wykorzystywane rzadziej niż w Brandenburgii.

\section{UZUPEENIAJĄCE SIĘ TEORIE — FALSYFIKACJA TRZECIEJ HIPOTEZY}

Kolejna hipoteza tych badań, według której wysoki kapitał społeczny wyklucza możliwość opisu rzeczywistości w kategoriach postdemokratycznych, została sfalsyfikowana. W obu społecznościach widoczne są oznaki myślenia w kategoriach postdemokratycznych, chociaż mieszkańcy Brandenburgii rozporządzają bogatymi zasobami kapitału społecznego.

Należy w tym kontekście rozróżnić rozumienie demokracji lokalnej i demokracji reprezentatywnej. Wysoki kapitał społeczny pozytywnie wpływa na funkcjonowanie demokracji lokalnej. Ta funkcjonuje w Brandenburgii lepiej niż na Podlasiu, gdzie zasoby kapitału społecznego są mniejsze. Mimo to mieszkańcy żadnego $z$ regionów nie czują się podmiotami działań politycznych, postrzegają się raczej jako łatwy do wykorzystania obiekt w zglobalizowanym świecie, w którym dominują interesy ekonomiczne.

Wysoki kapitał społeczny, znajdujący wyraz w lokalnych inicjatywach, do pewnego stopnia osłabia tendencje postdemokratyczne. Ludzie angażujący się lokalnie działają $w$ rozmaitych organizacjach. Wiedza i umiejętności przez poszczególne osoby wnoszone w struktury organizacji oraz zdobywane tam doświadczenia są z pożytkiem wykorzystywane $\mathrm{w}$ procesie reprezentowania ich potrzeb i interesów na wyższych poziomach demokratycznego systemu podejmowania decyzji i administrowania. W Brandenburgii krytyka systemu jest równie silna, a może nawet silniejsza niż na Podlasiu, ale ludzie, którzy się angażują, nie tracą nadziei, że przez swoją aktywność do osiągnięcia wspólnych celów zdołają wykorzystać również te struktury, które nie są legitymizowane bezpośrednio demokratycznie. Chodzi na przykład o korzystanie z przydzielanych przez Komisję Europejską grantów na działania społeczne, a także o reprezentację interesów grupowych w strukturach unijnych.

Analizy teoretyczne i wyniki badań empirycznych pozwalają stwierdzić, że żadna $z$ dwóch przywoływanych teorii nie jest $w$ stanie $w$ pełni wyjaśnić procesów przemian społeczno-politycznych w badanych regionach. Teorie kapitału społecznego i postdemokracji zbliżają się do siebie w pewnych punktach. Ujęcie kapitału społecznego pomaga lepiej zrozumieć mechanizmy funkcjonowania demokracji lokalnej. Teoria postdemokracji umożliwia lepsze zrozumienie procesów apatii politycznej i kryzysu demokracji reprezentatywnej. Wysoki kapitał społeczny osłabia apatię polityczną, ale jej nie wyklucza.

\section{PERSPEKTYWY NA PRZYSZŁOŚĆ}

Przedstawione badania pozwoliły opisać aktualny stan i procesy przekształceń kapitału społecznego Podlasia i Brandenburgii oraz zmiany sposobu ro- 
zumienia demokracji przez ich mieszkańców. Jakie perspektywy na przyszłość można dzięki temu zarysować?

Przeddemokratyczne formy społeczne obszarów wiejskich na Podlasiu ulegną dalszemu osłabieniu. Proces ten trwa już od dłuższego czasu, a nawet intensyfikuje się w wyniku przemian demograficznych i gospodarczych, zmiany systemu wartości, globalizacji i tendencji do indywidualizacji. Czy w tej sytuacji jest szansa, że na Podlasiu ukształtuje się społeczność w pełni demokratyczna? Niewielka. Brakuje bowiem kapitału społecznego typu wspólnotowego, a już widoczne są tendencje postdemokratyczne. Jeśli dalej będzie się rozwijał kapitał społeczny typu stowarzyszeniowego, to może to, jak wykazały badania, sprzyjać funkcjonowaniu demokracji lokalnej, co jednak nie wpłynie na ocenę demokracji reprezentatywnej, która z jednej strony zależy od poziomu elit politycznych, z drugiej zaś od sytuacji ekonomicznej rodzin. Poprawa sytuacji ekonomicznej wpływa na lepszą ocenę systemu demokratycznego, co nie zmienia faktu, że ocena ta odwołuje się bardziej do ekonomii niż do polityki.

Wiedza na temat mechanizmów demokratycznych i możliwości, jakie daje demokracja reprezentatywna, jest na Podlasiu znikoma. System demokratyczny jest postrzegany poprzez mechanizmy występujące na poziomie lokalnym. Brakuje zrozumienia tego, że demokracja na wyższych poziomach podejmowania decyzji i zarządzania funkcjonuje na innych zasadach, na zasadach reprezentacji, i nie jest możliwe, by na poziomie państwa każdy obywatel miał bezpośredni wpływ na politykę krajową. Jeszcze więcej niezrozumienia obserwuje się $\mathrm{w}$ odniesieniu do organizacji ponadnarodowych. Większość obywateli nie potrafi odróżnić zadań i kompetencji określonych instytucji na różnych poziomach zarządzania. Wielu Podlasian jest bardzo nieufnych i ostrożnych wobec instytucji ponadnarodowych, przede wszystkim wobec Unii Europejskiej. Unia często jest przez nich określana jako „biurokratyczny potwór” lub uważana za zwykłego dostarczyciela gotówki. Dopóki wiedza o możliwościach działań na poziomie ponadnarodowym pozostaje tak uboga, dopóty istniejące tam szanse wzmocnienia demokracji nie mogą być w pełni wykorzystane. Dlatego zarówno polscy politycy, media, jak i organizacje z sektora pozarządowego powinny zabiegać o to, by przybliżyć ludziom reguły i pryncypia systemu demokratycznego. Jeśli nie uda się zmobilizować elit do takich działań, to Podlasie będzie narażone na wzmocnienie tendencji postdemokratycznych.

Także w Brandenburgii można przeciwdziałać takim tendencjom. Obecnie demokracja jest tam silniejsza niż na Podlasiu. Demokracja lokalna czerpie z lokalnych i regionalnych źródeł kapitału społecznego, a wiele urzędów i polityków dba o to, by zaangażowanie obywatelskie rosło. Apatia polityczna wiąże się tu przede wszystkim $z$ oceną polityki na poziomie krajowym i ponadnarodowym. Obywatele postulują daleko idące reformy krajowych i międzynarodowych instytucji demokratycznych, często wysuwają nawet własne propozycje niezbędnych, ich zdaniem, zmian. Dopóki problematyka demokracji nie jest im 
obojętna, dopóty demokracja w Brandenburgii pozostaje niezagrożona. Niechęć wobec polityki nie przeobrazi się $\mathrm{w}$ niechęć do demokracji.

Przeciętny obywatel Brandenburgii lepiej rozumie reguły demokracji niż przeciętny mieszkaniec Podlasia. W tym niemieckim regionie należałoby wykorzystać gotowość mieszkańców do powszechnej debaty, wielu z nich wyraża chęć do dyskusji na dotyczące wspólnoty tematy, a także gotowość do zawierania kompromisów. Wierzą, że w ten sposób można osiągać cele, które w ostatecznym rozrachunku przyczyniają się do budowania dobra wspólnego. Jednocześnie krytykują brak możliwości udziału w takich debatach na poziomie krajowym i ponadnarodowym. Również tu wiedza na temat mechanizmów demokracji reprezentatywnej oraz funkcjonowania organizacji ponadnarodowych pozostawia wiele do życzenia. Politycy, media i organizacje pozarządowe powinni - wykorzystując istniejące zasoby kapitału społecznego - poprawić wiedzę obywateli o demokracji.

Zadaniem dla wszystkich, którzy żyją w czasie wielkich przemian społecznych i gospodarczych, a którym idee i cele demokracji nie są obojętne, jest poszukiwanie nowych rozwiązań i nowych dróg rozwoju. Należy przy tym korzystać z dostępnych zasobów kapitału społecznego. Jako przyczynek do dalszych refleksji na temat przyszłości demokracji w czasach jej kryzysu zacytuję słowa znanego teoretyka demokracji Ralfa Dahrendorfa (2002, s. 8), który $\mathrm{w}$ jednym $\mathrm{z}$ wywiadów powiedział:

"Chociaż wciąż wierzę w pryncypia demokracji i postrzegam się jako ich zagorzały obrońca, jednocześnie jestem przeświadczony, że musimy na nowo przemyśleć podstawowe założenia demokracji $\mathrm{w}$ świetle fundamentalnych zmian, które w żadnej mierze nie są zakończone. Powiedziałbym, że wkroczyliśmy dziś już w fazę, którą można określić jako postdemokrację, jednak nie zwalnia to nas z obowiązku myślenia o projekcie «nowej demokracji»".

\section{BIBLIOGRAFIA}

Crouch Colin, 2004, Post-Democracy, Polity Press, Cambridge.

Dahrendorf Ralf, 2002, Die Krisen der Demokratie. Ein Gespräch mit Antonio Polito, C.H. Beck, München.

Fazlagić Jan, Kapitat społeczny w Polsce (http://www.fazlagic.egov.pl/artykul.php? artykul $=8 \&$ zakladka $=4)$.

Gabriel Oskar W. i in., 2002, Sozialkapital und Demokratie. Zivilgesellschaftliche Ressourcen im Vergleich, WUV, Wien.

Gehmacher Ernst, 2004, Sozialkapital. Basisinformationen, Dokument des österreichischen Lebensministeriums (http://umwelt.lebensministerium.at/article/ articleview/26519/1/7804).

Guéhenno Jean-Marie, 1996, Das Ende der Demokratie, Verlag Dtv, München.

Jörke Dirk, 2005, Auf dem Weg zur Postdemokratie, „Leviathan” t. 33, nr 4.

Rancière Jacques, 1997, Demokratie und Postdemokratie, w: Badiou Alain i in., Politik der Wahrheit, Turia und Kant Verlag, Wien. 
Reißig Rolf, 1994 Ostdeutschland - Der „deutsche Sonderweg” der Transformation, „Welt-Trends", nr 3.

TNS, 2006, Freiwilliges Engagement in Brandenburg 1999-2004 im Trend: Ehrenamt, Freiwilligenarbeit und bürgerschaftliches Engagement, Infratest Sozialforschung, München.

Tönnies Ferdinand,1988, Wspólnota $i$ stowarzyszenie, tłum. Małgorzata Łukasiewicz, PWN, Warszawa.

Wolin Sheldon, 2001, Tocqueville between Two Worlds: The Making of a Political and Theoretical Life, Princeton University Press, Princeton.

\section{THE PERCEPTION OF DEMOCRACY AND SOCIAL CAPITAL COMPARATIVE STUDY OF PODLASIE AND BRANDENBURG}

\section{Summary}

This essay presents results of comparative research which was carried out in one region in Eastern Poland - Podlasie - and one region in Eastern Germany - Brandenburg. The research compared the influence of social capital on the understanding of democracy among the citizens. The theoretical basis for this survey was the theory of post-democracy. One of the issues considered was the level of democratic development represented by Podlasie and Brandenburg. Are they in the pre-democratic, democratic or post-democratic phase? The essay analyses afterwards what chances both regions have for the full development of democracy and how one can use the resources of social capital to revise the understanding of democracy among the citizens of Podlasie and Brandenburg.

\section{Key words/słowa kluczowe}

democracy /demokracja; social capital / kapitał społeczny, Eastern Poland / wschodnia Polska; Eastern Germany / wschodnie Niemcy 